\title{
Smoke measurements during Gestosa-2002 experimental field fires
}

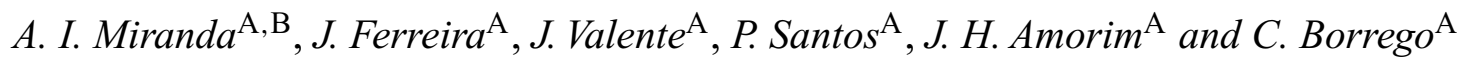

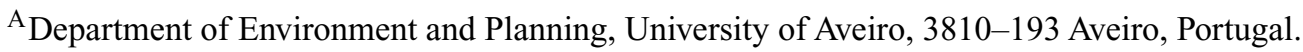 \\ ${ }^{\mathrm{B}}$ Corresponding author. Telephone: +351 234 370200; fax: +351 234 429290; email: aicm@dao.ua.pt
}

\begin{abstract}
Currently, there is a growing awareness that smoke produced during forest fires can expose individuals and populations to hazardous concentrations of air pollutants. Aiming to contribute to a better understanding of the air pollution phenomenon associated with forest fires, this paper presents and analyses the atmospheric emissions and air quality concentration measurements performed in the 2002 fire experiments at Gestosa, Central Portugal. Two vehicles were equipped with a meteorological station and air quality analysers that were turned on continuously to acquire concentrations of particulate matter, nitrogen oxides and carbon monoxide. Nitrogen and sulfur dioxides were measured using a grid of fixed passive samplers. Also, firefighters and research-team members used passive samplers during the experiments in order to estimate the human exposure to these pollutants. Measurements of volatile organic compound emissions, using Tedlar bags, were carried out. Results were analysed taking into account not only the concentration values but also the variables involved, such as the combustion phase and the meteorology, and identifying possible relationships between them. Despite the small size of the burning plots when compared to wildfires, the measured levels of pollutants were however considerable, indicating the effect of these experiments on the local air quality and stressing the serious levels of air pollution that can be expected during wildfires.
\end{abstract}

Additional keywords: air quality; forest fire emissions.

\section{Introduction}

Concern associated with smoke from forest fires has been increasing during recent years. The severe air pollution episodes caused by fires in Amazonia (Brazil), Indonesia and the Philippines in 1997-1998, and more recently in Australia and Russia, has drawn worldwide attention to this problem. In Portugal, the summer of 2003 was considered the most devastating of the last decade, with fewer fires but $\sim 4$ times the average area burned annually. Also a clear effect on the air quality values measured by the national monitoring network was found (Martins et al. 2004). Currently, there is a growing awareness that smoke from forest fires can expose individuals and populations to hazardous air pollutants, stressing the importance of knowing in what conditions serious health effects can be expected and what procedures should be followed to prevent its occurrence or to diminish its effects. This concern also is associated with the use of prescribed fires, namely in Australia and North America where this fire management technique is used frequently. The World Health Organization (WHO) has developed policies and guidelines to reduce the health impacts of smoke generated during vegetation burning (WHO/UNEP/WMO 1999) and the legislative requirements regarding air quality should be met when performing prescribed burns in North America (Riebau and Fox 2001).
The type and amount of products emitted into the atmosphere from biomass burning are extremely dependent on the type of fuel, fire line intensity, fuel moisture, wind and fire temperature. The chemistry, phase (flaming and smouldering) and efficiency of the combustion process are of fundamental importance when estimating forest fire emissions. The effects of smoke on air quality cannot be determined through the estimation of emissions alone. Air pollution assessment requires estimates of the pollutants concentration some distance from sources with known emission characteristics and, in this respect, the atmospheric flow has a fundamental role in smoke transport and dispersion.

A significant body of research results can be found in the literature about the quantification of gaseous and particulate emissions from fires and the calculation of emission factors for both wildfires and prescribed burns. Andreae and Merlet (2001) presented and reviewed emission factors for biomass burning. Also, the WHO has produced a complete document on this subject (WHO/UNEP/WMO 1999), and Ward and Radke (1993) reviewed the methods to measure emissions from vegetation fires, ranging from very small controlled combustion experiments to satellite techniques. The USDA Forest Service has developed intensive measurements of smoke exposure among firefighters during both prescribed burns (Reinhardt et al. 2000) and wildfires (Reinhardt and 
Ottmar 2000). In the scope of the European Commission (EC) ERAS Project ('Extension Retardant Application System'), a portable device for smoke analysis is being tested for the measurement of air pollutant concentrations during forest fires (NTUA 2004). Forest fire detection by smoke sensing with light detection and ranging (LIDAR) technology has led to some interesting results (Utkin et al. 2003). However, air pollutant concentration data acquired during forest fires and accompanied by other important data, like meteorology, visibility, fire and combustible characteristics, are still limited and it is not possible to completely understand and evaluate the effects of forest fires on air quality. The main purpose of this work is to contribute to a better understanding of forest fires as a source of pollutants to the atmosphere.

This paper presents the concentration values of a set of air pollutants measured during experimental fires in Central Portugal, Gestosa-2002, and analyses the acquired values in an integrated way, taking into account other variables involved, such as fire stage and meteorology, and identifying possible correlations in order to contribute to a better understanding of the air pollution phenomenon associated with forest fires. This work was performed within the scope of the SPREAD Project ('Forest Fire Spread Prevention and Mitigation'), a research project funded by the EC, and several other teams were involved. Part of the data used in the paper results from these teams' activities. The particular location of the study area, southern Europe, should be stressed because despite the intense occurrence of forest fires in this region, the information concerning air quality impacts is mainly available from other parts of the world.

\section{Methodology}

The burning experiments performed since 1998 at Central Portugal, Gestosa, aim to collect a large range of different but complementary experimental data, which should be used to support the development of new concepts and models and to validate existing methods or models in various fields of fire management (Viegas et al. 2002). These experiments, involving several research teams and covering a very extensive characterisation of variables related to fire behaviour, constitute a valuable source of fire-related data within the European territory and a particularly important opportunity to measure and analyse air pollutants concentrations during experimental field fires.

From the first field campaign (1998) until the last one (2004) it is possible to discern a clear evolution of the measurement approaches and techniques applied, as a result of the knowledge acquired during the previous burnings and the optimisation of the experimental procedures (Miranda and Borrego 2002). During 2002 main burns, conducted on 30 and 31 May, measurements of atmospheric emissions and air quality concentrations were taken as described below. Selection of the specific burning days is very dependent on weather conditions. Usually burning experiments last two spring days and everything is organised towards the end of May, beginning of June, aiming to avoid rainy days and the beginning of the season when experimental fires are not allowed.

\section{Study area characteristics}

The study area was located in Central Portugal $\left(40^{\circ} 15^{\prime} \mathrm{N}\right.$, $8^{\circ} 10^{\prime} \mathrm{W}$ ), in a hillside of 'Serra da Lousã' with altitudes between 800 and $950 \mathrm{~m}$. To guarantee the safety of the personnel and equipment involved and to assure a good organisation of the experimental program, the area was divided into 10 plots with regular shapes and different dimensions, which were separated by fuel breaks with widths between 5 and $15 \mathrm{~m}$, to limit fire spread and to keep it inside the desired boundaries (Viegas 2002). These experimental burning plots, represented in the photograph of Fig. 1, were established within Forest Service lands, and within the Gestosa forestry perimeter.

Systematic vegetation sampling was carried out along the plots (Viegas 2002). Non-destructive sampling along linear transects was made to determine vegetation cover, species composition and vegetation height. For each plot, the results from previous destructive samplings were used to evaluate the biomass of each species. Table 1 presents a set of data that characterise the experimental plots. The plots areas range from $\sim 0.4$ (plot 517) to 1 ha (plot 520). The plots are SW and SSW oriented, with a terrain slope varying between 17 and $27^{\circ}$ (smaller plots present higher slopes). The existing vegetation consists mainly of continuous shrubs (Erica umbellata, Erica australis and Chamaespartium tridentatum) with some isolated Pinus pinaster trees. Fuel properties were assumed as homogeneous within each plot (see Table 1).

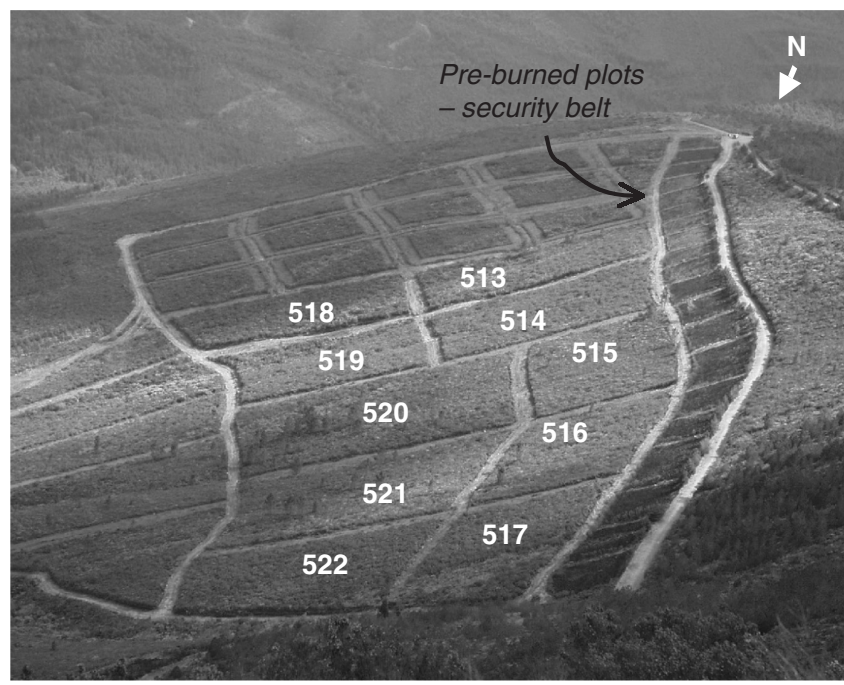

Fig. 1. Gestosa-2002 study area, with location of experimental plots and respective serial numbers. 


\section{Measuring equipment and techniques}

During the experimental fires, which occurred on warm and dry days, temperature, humidity and wind speed and direction were measured at several locations, near the fire plots. Specific techniques and equipment were used to obtain the concentrations of different pollutants. Table 2 summarises the applied measuring techniques.

Two luggage vans, both located near the burning plots, were equipped with meteorological measuring equipment and air quality analysers. Van 1 measured concentrations of particles with an aerodynamic diameter lesser than $2.5 \mu \mathrm{m}$ $\left(\mathrm{PM}_{2.5}\right)$, and van 2 measured particles smaller than $10 \mu \mathrm{m}$ $\left(\mathrm{PM}_{10}\right)$, nitrogen dioxide $\left(\mathrm{NO}_{2}\right)$ and nitric oxide $(\mathrm{NO})$, and carbon monoxide $(\mathrm{CO})$. Table 3 presents the distance between the vans and the centre of the nearest plots. In Fig. 2, a photo of van 2 and its air quality equipment is shown.
The continuous acquisition of $\mathrm{NO}$ and $\mathrm{NO}_{2}$ concentrations in air was performed using the automatic equipment Environnement AC $31 \mathrm{M}^{\mathrm{TM}}$ (dual chamber chemiluminescent nitrogen oxides; Environment S.A., Poissy, France). CO was measured continuously with the Environnement CO11M analyser, whose functioning principle is based on the selective absorption of infrared radiation by the $\mathrm{CO}$ molecules. To monitor $\mathrm{PM}_{10}$ and $\mathrm{PM}_{2.5}$ concentrations, two Environnement MP101M analysers were used with adequate sampling inlets for each diameter. A $\beta$-gauge mass monitor determines the particle's mass.

Taking into account one of the advantages of passive samplers (Radiello equipment), i.e. its portability, a grid of $\mathrm{NO}_{2}$ and sulfur dioxide $\left(\mathrm{SO}_{2}\right)$ samplers was defined according to the local dominant winds, at the top of the experimental field and along two lines, allowing us to obtain a larger spatial cover
Table 1. Main characteristics of the experimental plots (Viegas 2002)

\begin{tabular}{lrrrrrr}
\hline Plot & \multicolumn{2}{c}{ Dimension (m) } & $\begin{array}{c}\text { Slope } \\
\left({ }^{\circ}\right)\end{array}$ & $\begin{array}{c}\text { Mean } \\
\text { height } \\
(\mathrm{m})\end{array}$ & $\begin{array}{c}\text { Total } \\
\text { cover } \\
(\%)\end{array}$ & $\begin{array}{c}\text { Fuel load } \\
\left(\mathrm{kg} \mathrm{m}^{-2}\right)\end{array}$ \\
\hline 513 & 58 & 97 & 21 & 1.2 & 89 & 6.3 \\
514 & 85 & 90 & 21 & 1.1 & 97 & 9.9 \\
515 & 87 & 53 & 27 & 0.8 & 98 & 5.4 \\
516 & 101 & 51 & 22 & 1.1 & 88 & 8.7 \\
517 & 86 & 52 & 24 & 1.3 & 100 & 11.1 \\
518 & 58 & 108 & 17 & 1.6 & 97 & 11.0 \\
519 & 89 & 91 & 21 & 1.2 & 98 & 7.8 \\
520 & 89 & 109 & 18 & 1.2 & 95 & 5.7 \\
521 & 87 & 99 & 19 & 1.3 & 100 & 6.6 \\
522 & 68 & 90 & 18 & 1.2 & 100 & 7.2
\end{tabular}

Table 3. Average distance between the vans and nearest plots

\begin{tabular}{lcc}
\hline Van & Plot & Distance $(\mathrm{m})$ \\
\hline 1 & 515 & 200 \\
& 516 & 110 \\
& 517 & 65 \\
& 521 & 150 \\
& 522 & 125 \\
& 513 & 130 \\
& 514 & 75 \\
& 515 & 90 \\
& 516 & 150 \\
& 518 & 200 \\
& 519 & 170 \\
& 520 & 180 \\
\hline
\end{tabular}

Table 2. Summary of air pollutant measurement techniques during Gestosa-2002 experiments

\begin{tabular}{|c|c|c|c|c|}
\hline Pollutant & Technique & Type of data & Equipment & Characteristics \\
\hline $\mathrm{NO}_{\mathrm{x}}\left(\mathrm{NO}, \mathrm{NO}_{2}\right)$ & Automatic equipment, van 2 & $\begin{array}{l}\text { Continuous measurement: } \\
1 \text { min average }\end{array}$ & $\begin{array}{l}\text { Environnement } \\
\text { AC } 31 \mathrm{M}^{\mathrm{TM}}\end{array}$ & $\begin{array}{l}\text { Range: } 0-10 \mathrm{ppm} \text { (programmable) } \\
\text { Noise: } 0.17 \mathrm{ppb} \\
\text { Lower detectable limit: } 0.35 \mathrm{ppb} \\
\text { Response time: automatic and } \\
\text { programmable (minimum } 20 \mathrm{~s} \text { ) }\end{array}$ \\
\hline $\mathrm{CO}$ & Automatic equipment, van 2 & $\begin{array}{l}\text { Continuous measurement: } \\
1 \text { min average }\end{array}$ & $\begin{array}{l}\text { Environnement } \\
\text { CO11 } \mathrm{M}^{\mathrm{TM}}\end{array}$ & $\begin{array}{l}\text { Range: } 0-200 \mathrm{ppm} \text { (programmable) } \\
\text { Noise: } 0.025 \mathrm{ppm} \\
\text { Lower detectable limit: } 0.05 \mathrm{ppm} \\
\text { Response time: automatic and } \\
\text { programmable (minimum } 30 \mathrm{~s} \text { ) }\end{array}$ \\
\hline \multicolumn{5}{|l|}{ Particulate matter } \\
\hline $\mathrm{PM}_{2.5}$ & Automatic equipment, van 1 & $\begin{array}{l}\text { Continuous measurement: } \\
15 \text { min average }\end{array}$ & $\begin{array}{l}\text { Environnement } \\
\text { MP101 } M^{\mathrm{TM}}\end{array}$ & $\begin{array}{l}\text { Range: } 0-10000 \mu \mathrm{g} \mathrm{m}^{-3} \\
\text { (programmable) }\end{array}$ \\
\hline $\mathrm{PM}_{10}$ & Automatic equipment, van 2 & $\begin{array}{l}\text { Continuous measurement: } \\
15 \text { min average }\end{array}$ & $\begin{array}{l}\text { Environnement } \\
\text { MP101 } \mathrm{M}^{\mathrm{TM}}\end{array}$ & $\begin{array}{l}\text { Range: } 0-10000 \mu \mathrm{g} \mathrm{m}^{-3} \\
\text { (programmable) }\end{array}$ \\
\hline $\mathrm{NO}_{2}, \mathrm{SO}_{2}$ & $\begin{array}{l}\text { Passive samplers and } \\
\text { laboratory analysis }\end{array}$ & $\begin{array}{l}\text { Variable sampling period } \\
\text { (see Tables 5-7): } 1 \mathrm{~h} \text { average }\end{array}$ & Radiello & \\
\hline VOC & $\begin{array}{l}\text { Sampling in Tedlar bags and } \\
\text { laboratory analysis with a FID }\end{array}$ & Instantaneous sampling & & \\
\hline
\end{tabular}



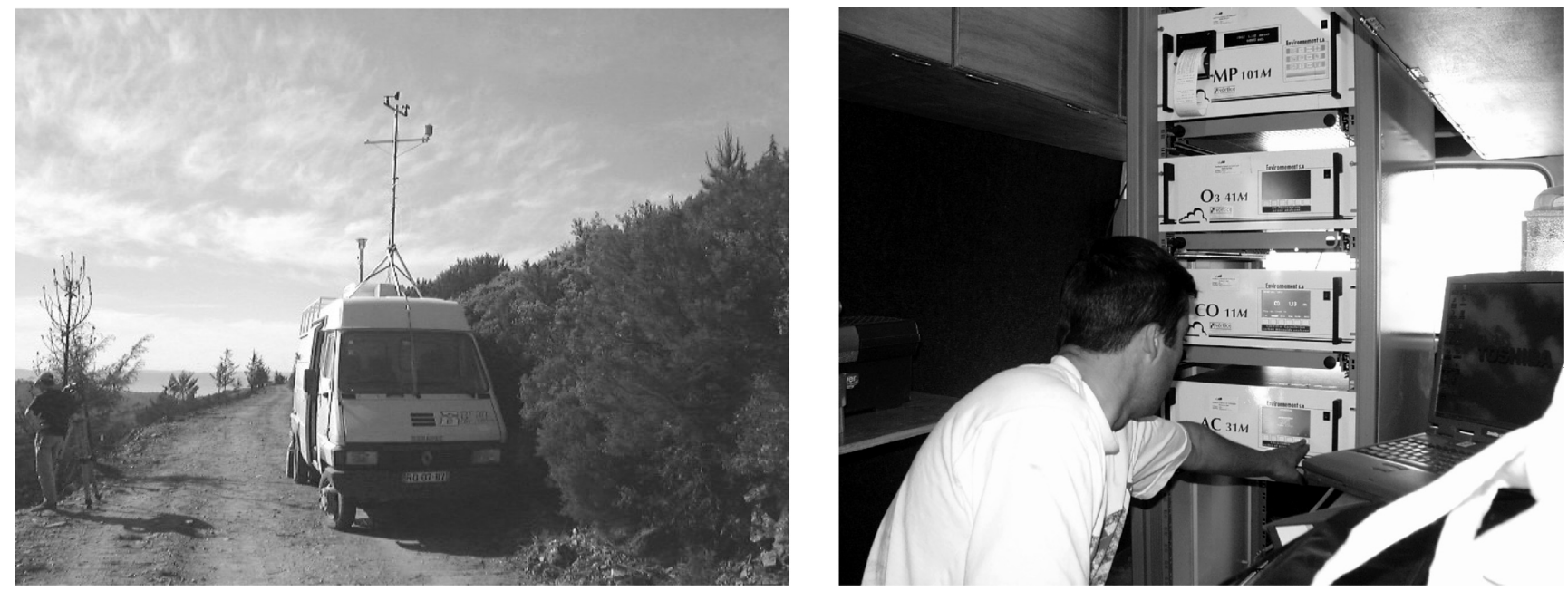

Fig. 2. Photo of van 2 and its air quality equipment.

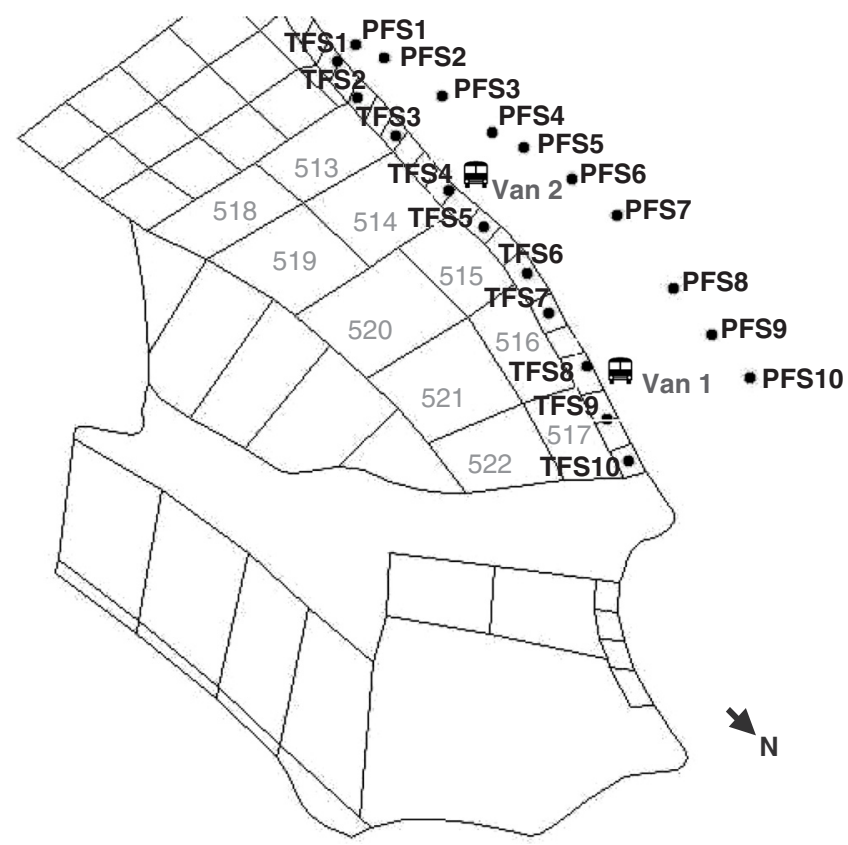

Fig. 3. Gestosa-2002 study area, with location of measuring equipment.

of the pollutants' dispersion. The sampling was performed with triethanolamine diffusivity passive samplers and the subsequent laboratory analyses were made by ionic chromatography. Some of the samplers were changed at various times during a day, aiming to evaluate how the characteristics of the burned plots influenced the air pollutant concentrations. Replicates of each passive sampler were used. In Fig. 3 the location of the two lines of passive samplers is presented; the first one, in which the samplers were replaced one or two times a day (temporary-fixed samplers; TFS), was closer to the burning area, while the other one contained the
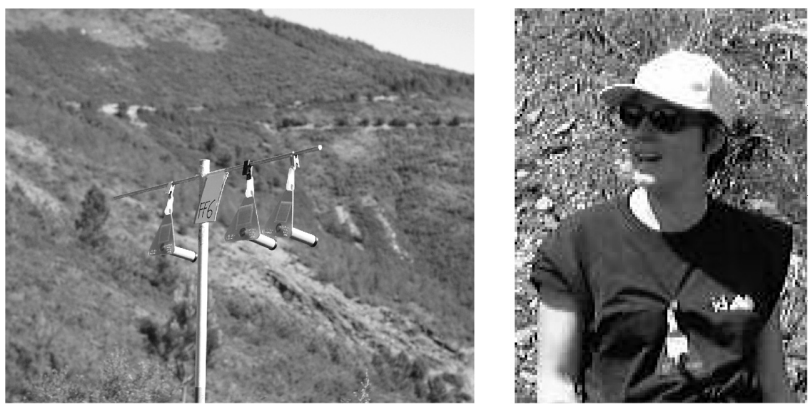

Fig. 4. Photo of passive samplers.

devices that sampled during the whole day (permanent-fixed samplers; PFS).

Various firefighters and members of the research team carried a mobile passive sampler (MS) during the experiments in order to estimate the human exposure to $\mathrm{NO}_{2}$ and $\mathrm{SO}_{2}$. Figure 4 shows an example of the passive samplers used during the experiments, namely the fixed sampler at location 6 and a member of our team using one diffusive tube.

Measurements of volatile organic compound (VOC) emissions were carried out during the flaming and the smouldering phases of each plot, by pumping the smoke into Tedlar bags for subsequent laboratory analyses with a flame ionisation detector (FID).

\section{Experimental procedure}

Information concerning the set-up and development of the experiments, namely the beginning and the end time of each plot burning, and some particular techniques to ignite and extinguish the fire that were tested during Gestosa-2002, is given in Table 4. Burning time concerns the period from ignition until the extinguishment of the flames. 
Table 4. Plot burning information and time schedule

\begin{tabular}{|c|c|c|c|c|c|}
\hline \multirow[t]{2}{*}{$\overline{\text { Day }}$} & \multirow[t]{2}{*}{ Plot } & \multicolumn{2}{|c|}{ Local time } & \multirow{2}{*}{$\begin{array}{l}\text { Burning time } \\
\text { (min) }\end{array}$} & \multirow[t]{2}{*}{ Observations } \\
\hline & & Begin & End & & \\
\hline \multirow{6}{*}{30 May } & 513 & 10:19 & $10: 44$ & 25 & Linear ignition at top and bottom \\
\hline & 517 & $11: 26$ & $11: 44$ & 18 & Linear ignition at top, upper third pyrotechnic \\
\hline & 516 & $12: 21$ & $12: 28$ & 7 & Single line at the bottom \\
\hline & 514 & $13: 11$ & $13: 30$ & 19 & Hoses of explosives filled with water \\
\hline & 515 & $16: 20$ & $16: 39$ & 19 & Hoses of explosives filled with water \\
\hline & 518 & $17: 04$ & $18: 05$ & 61 & Stronger wind blowing downslope \\
\hline \multirow[t]{4}{*}{31 May } & 522 & $11: 00$ & $11: 30$ & 30 & Safety burn \\
\hline & 521 & $12: 00$ & $12: 30$ & 30 & Point ignition \\
\hline & 520 & $13: 45$ & $14: 03$ & 48 & Hoses of explosives filled with water \\
\hline & 519 & $14: 32$ & $14: 51$ & 19 & Oblique ignition \\
\hline
\end{tabular}

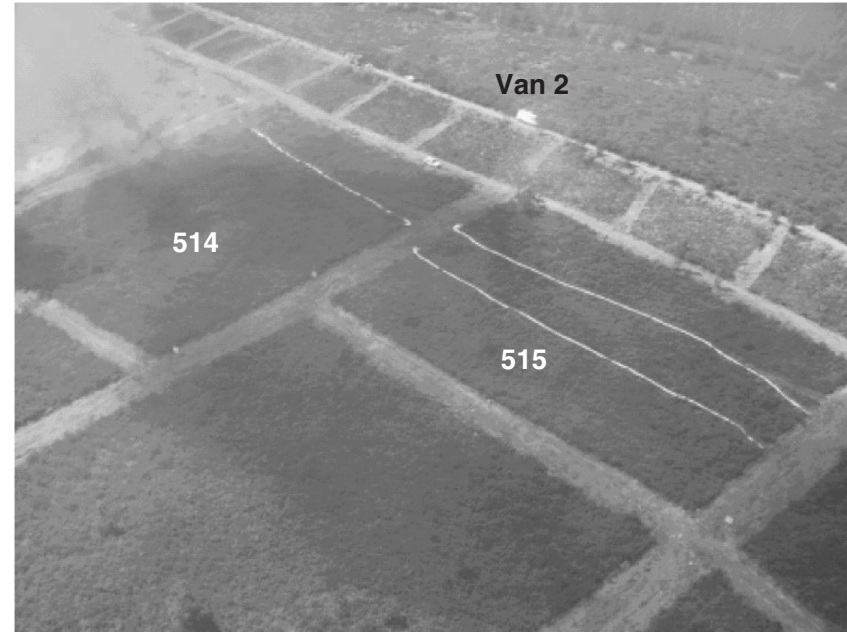

Fig. 5. Aerial view of hoses (white lines) in plots 514 and 515 .

On the morning of the first day, plots 513 and 517 were burned. In the first one, linear ignition was used at its top and then bottom. Plot 517 was burned by linear ignition on the top and then linear ignition on its upper third with pyrotechnic devices (Viegas et al. 2002).

One of the most striking events of Gestosa-2002 was the test with the German hoses filled with water and with a detonating cord that exploded just before the fire reached them (Viegas 2002). This technique was applied to plots 514 and 515 as it can be seen in Fig. 5. The fire front was extinguished after a short time in these plots where the blasting hoses were used. Aiming to identify the influence of using this extinguishing technique, some of the passive diffusers closer to the burning area were replaced before burning plot 514 (TFS4, TFS5, TFS6 and TFS7) and the others were changed between the plot 514 and 515 burns.

\section{Presentation and analysis of results}

Figure 6 presents the meteorological and air quality data acquired during the first day of the experiments by the automatic equipment installed inside the luggage vans. Only data acquired during the first day of experiments are presented because for the second day, smoke from only one burning plot impacted a single van, and measured values were similar to those of the first day. Dotted lines represent the beginning and the end time for each burning plot. Between 14:30 and 16:00 there are no data because it was lunchtime and experiments were stopped. Limit air quality concentration values settled by the European Legislation are also represented in the graphs, namely the daily average for $\mathrm{PM}_{10}\left(50 \mu \mathrm{g} \mathrm{m}^{-3}\right)$, established in the Council Directive 1999/30/EC; the $8 \mathrm{~h}$ average for $\mathrm{CO}\left(10 \mathrm{mg} \mathrm{m}^{-3}\right)$ defined by 2000/69/EC; and the hourly average for $\mathrm{NO}_{2}\left(200 \mu \mathrm{g} \mathrm{m}^{-3}\right)$ implemented by 1999/30/EC. However, concerning $\mathrm{NO}_{2}$ a margin of tolerance, established for the year 2002, permits a maximum hourly average of $289 \mu \mathrm{g} \mathrm{m}^{-3}$.

It is possible to verify that the burns occurred with weak winds (rounding $2 \mathrm{~m} \mathrm{~s}^{-1}$ ) blowing from NE to SE in the morning hours and changing towards NW during the afternoon. In the afternoon, burning of the first and second plots was influenced by a variable wind direction. This wind behaviour is closely related to the air pollutant concentrations measured in each van.

Notwithstanding the close location of the two vans, separated by $250 \mathrm{~m}$, they were affected by emissions coming from different plots according to the wind direction and demonstrating the considerable effect of topography over the wind field and, consequently, the smoke dispersion. Van 1 registered the influence of emissions from plots 517 (Figs 6, 7a) and 516, and van 2 the effects of plots 514 and 515 (Figs 6, $7 b, c)$. In Fig. 7, photos of plots 517, 514 and 515 burning are presented.

In general, air quality equipment registered the effect of fire emissions only after the end of each burn. This can be explained by the fact that, due to the extremely high temperatures reached during the flaming stage, which induce the formation of a convection column, the smoke plume was forced to rise, not reaching the vans that were located at the vicinity of the plots. With the diminishing of the amount of heat released, local winds became stronger than these thermally induced circulations, transporting the smoke towards 
(a)

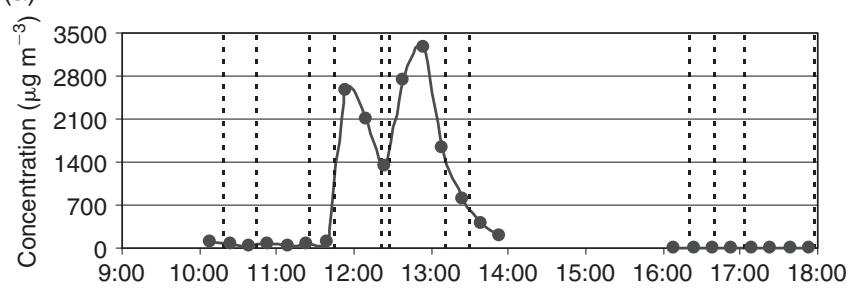

(c)

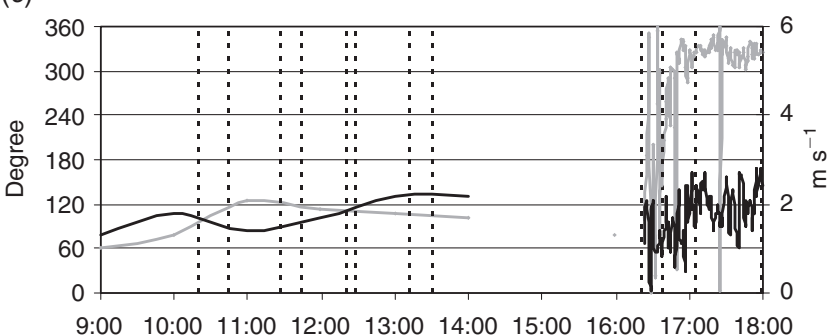

(e)

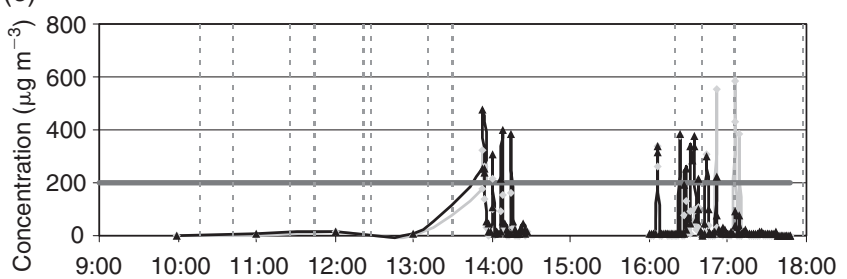

(b)

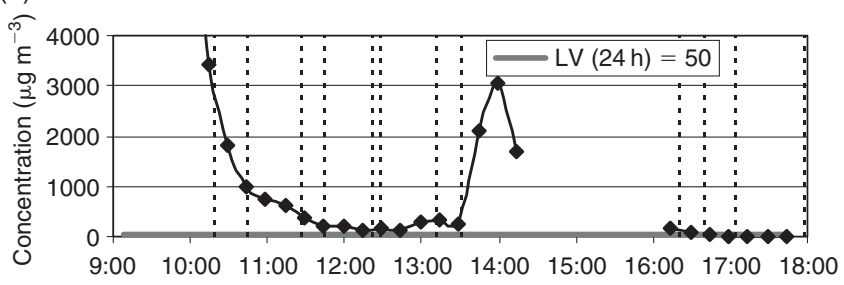

(d)

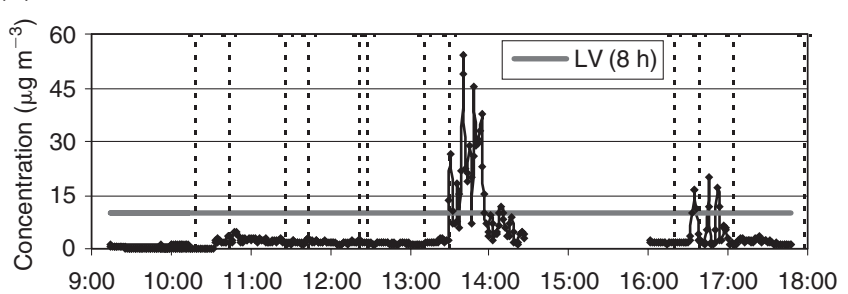

$\mathrm{NO}\left(\mu \mathrm{g} \mathrm{m}^{-3}\right) \longleftarrow \mathrm{NO}_{2}\left(\mu \mathrm{g} \mathrm{m}^{-3}\right) \longleftarrow \mathrm{LV}^{-3} \mathrm{NO}_{2}(1 \mathrm{~h})$

Fig. 6. $\mathrm{PM}_{2.5}$ (van 1) (a), $\mathrm{PM}_{10}$ (van 2) (b), wind speed and direction (van 2) (c), $\mathrm{CO}$ (van 2) (d), and $\mathrm{NO}$ and $\mathrm{NO}_{2}($ van 2) (e) values measured during the first day of experimental fires (vertical dotted lines represent the burning time of each burning plot).
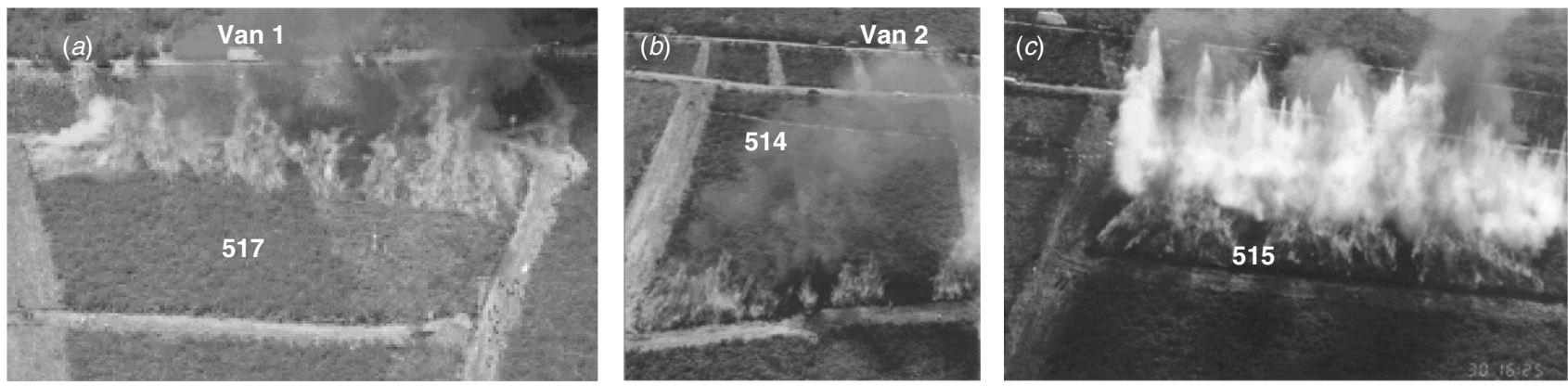

Fig. 7. Photos of plots $517(a), 514(b)$ and $515(c)$ (at the precise moment of the explosive hoses detonation) fire front.

the vans. The first burn of the experiments, plot 513, did not affect the air quality values measured in either van because the wind blew from the east and the smoke plume did not reach the vans.

As can be seen in Fig. $7 a$, van 1 was affected by plot 517 emissions. The van was located just above the plot $(65 \mathrm{~m}$ distance) and wind blew from the SE, transporting the smoke in its direction. Fifteen minute-averaged $\mathrm{PM}_{2.5}$ concentrations reached $2500 \mu \mathrm{g} \mathrm{m}^{-3}$. The following burning plot also contributed to $\mathrm{PM}_{2.5}$ concentration values measured in van 1 , reaching even higher values $\left(3000 \mu \mathrm{g} \mathrm{m}^{-3}\right)$. The averaged concentration for the time period the equipment was functioning $(\sim 6 \mathrm{~h})$ is $646 \mu \mathrm{g} \mathrm{m}^{-3}$. Even considering that during the rest of the day the concentration was $0 \mu \mathrm{g} \mathrm{m}^{-3}$, the $24 \mathrm{~h}$ average is $160 \mu \mathrm{g} \mathrm{m}^{-3}$. Although there is no legislated value for $\mathrm{PM}_{2.5}$ in Europe, in the USA the legislation established a limit of $65 \mathrm{\mu g} \mathrm{m}^{-3}$ for a $24 \mathrm{~h}$ average. Both the peak and the average values correspond to a hazardous category of air quality and very low visibility, less than $1.4 \mathrm{~km}$ according to Core (2001).

Regarding the concentrations measured in van 2 , it should be stressed that the high $\mathrm{PM}_{10}$ values acquired at the beginning of the experiments are related to some problems with the warming up of the equipment. The data measured by van 2 were affected by emissions from the plots where explosive hoses were used (514 and 515). 
Table 5. Hourly averaged concentration values for permanent-fixed samplers (PFS)

\begin{tabular}{|c|c|c|c|c|c|c|}
\hline \multirow[t]{2}{*}{ PFS location } & \multicolumn{3}{|c|}{30 May 2002} & \multicolumn{3}{|c|}{31 May 2002} \\
\hline & Exposure period & $\mathrm{NO}_{2}\left(\mu \mathrm{g} \mathrm{m}^{-3}\right)$ & $\mathrm{SO}_{2}\left(\mu \mathrm{g} \mathrm{m}^{-3}\right)$ & Exposure period & $\mathrm{NO}_{2}\left(\mu \mathrm{g} \mathrm{m}^{-3}\right)$ & $\mathrm{SO}_{2}\left(\mu \mathrm{g} \mathrm{m}^{-3}\right)$ \\
\hline PFS1 & $9: 30-17: 47$ & 40 & 10 & $8: 40-16: 03$ & 30 & 7 \\
\hline PFS2 & $9: 29-17: 47$ & 35 & 11 & $8: 38-16: 00$ & 43 & 9 \\
\hline PFS3 & $9: 20-17: 45$ & 38 & 15 & $8: 35-15: 59$ & 31 & 9 \\
\hline PFS4 & $9: 10-17: 44$ & 47 & 19 & $8: 33-15: 52$ & 32 & 8 \\
\hline PFS5 & $9: 12-17: 42$ & 50 & 26 & $8: 30-15: 50$ & 31 & 7 \\
\hline PFS6 & $9: 10-17: 41$ & 47 & 13 & $8: 28-15: 50$ & 30 & 8 \\
\hline PFS7 & $9: 07-17: 39$ & 53 & 18 & $8: 25-15: 51$ & 30 & 10 \\
\hline PFS8 & $9: 04-17: 37$ & 48 & 17 & $8: 21-15: 48$ & 48 & 6 \\
\hline PFS9 & $8: 59-17: 34$ & 46 & 15 & $8: 19-15: 40$ & 22 & - \\
\hline PFS10 & $8: 55-17: 32$ & 45 & 14 & $8: 16-15: 37$ & 32 & 9 \\
\hline
\end{tabular}

$\mathrm{PM}_{10}$ concentrations acquired in van 2 during burning of plot 514 (Fig. $7 b$ ) were very high, reaching a maximum value of $3000 \mu \mathrm{g} \mathrm{m}^{-3}$ and an average value of $940 \mu \mathrm{g} \mathrm{m}^{-3}$ during the time the equipment was acquiring data $(\sim 6 \mathrm{~h})$. Making the same assumption made for the calculation of the $\mathrm{PM}_{2.5}$ average, if it is considered that during the other $18 \mathrm{~h}$ of the day the concentration was $0 \mu \mathrm{g} \mathrm{m}^{-3}$; the $24 \mathrm{~h}$ average is $235 \mu \mathrm{g} \mathrm{m}^{-3}$. This value is extremely high when compared with the European legislation, which sets a maximum of $50 \mathrm{\mu g} \mathrm{m}^{-3}$ for a $24 \mathrm{~h}$ average value. Also, the concentrations during the time of the experiment correspond to a hazardous category of air quality and very reduced visibility in that area, less than $1.4 \mathrm{~km}$ (Core 2001).

After this experiment, the filters had to be replaced and no data are available for the afternoon experiments (namely plot 515). Therefore, data presented in the Fig. 6 graphs, mainly zero values, are not reliable.

Still related to plot 514 are $\mathrm{CO}, \mathrm{NO}$ and $\mathrm{NO}_{2}$ values measured just after the end of the burning. $\mathrm{CO}$ concentrations are quite high, even exceeding the WHO (WHO 2000) and EPA (NAAQS) hourly limit values for this pollutant (30 and $40 \mathrm{mg} \mathrm{m}^{-3}$, respectively) during approximately half an hour, a fact that raises some concern. However, the $8 \mathrm{~h} \mathrm{limit}$ value established in European legislation was never exceeded. Wildland firefighters would probably be in contact with these high, and even higher, $\mathrm{CO}$ values. Measured $\mathrm{NO}_{2}$ and $\mathrm{NO}$ concentration values attained peak values of $400 \mu \mathrm{g} \mathrm{m}^{-3}$, but the hourly means, which attained a maximum of $189 \mu \mathrm{g} \mathrm{m}^{-3}$, never exceeded the hourly European limit for $\mathrm{NO}_{2}$. However, these levels could still be dangerous, mostly for firefighters working close to the fire front, because exposure to high $\mathrm{NO}_{2}$ concentration values harms the lungs and increases respiratory infections (Frampton et al. 1991). The explosive hoses placed in plot 515 (Fig. 7c) actuated sooner than those of plot 514; consequently, $\mathrm{CO}, \mathrm{NO}$ and $\mathrm{NO}_{2}$ concentrations were not so high.

Because of the wind direction change during the afternoon, smoke from plot 518 was transported in the opposite direction from the measuring equipment, showing the extreme influence of meteorological conditions, particularly unstable in mountainous environments, over the success of the work programmed.

Concerning $\mathrm{NO}_{2}$ and $\mathrm{SO}_{2}$ measurements with the passive sampling technique, Tables 5, 6 and 7 present the hourly averaged concentration values for PFS and TFS locations, and for MS. All passive $\mathrm{NO}_{2}$ samplers measured values higher than the rural background concentration value $6 \mu \mathrm{g} \mathrm{m}^{-3}$ (Penkett et al. 2003), indicating the influence of the smoke plume. The $\mathrm{SO}_{2}$ concentration values are not significant and are considerably smaller than the European legislated value of $350 \mu \mathrm{g} \mathrm{m}^{-3}$ (hourly average). Figure 8 schematically represents the spatial distribution of the measured $\mathrm{NO}_{2}$ concentration values for the first day of the experiments.

The comparison of hourly concentration values measured by permanent and temporary fixed samplers allows verification of the effect of distance on the values measured. In fact, although PFS samplers were acquiring during a longer period, their greater distance from the burning area is reflected in lower values. The changing of diffusive tubes, aiming to understand the effect of explosive hoses on $\mathrm{SO}_{2}$ and $\mathrm{NO}_{2}$ values, allowed verification that plots where this technique was tested emitted less $\mathrm{NO}_{2}$ and $\mathrm{SO}_{2}$, probably because the fire was extinguished sooner.

During the first day of the experiments, higher $\mathrm{SO}_{2}$ concentration values were acquired in TFS 7 and TFS8. This can be related to the emissions resulting from the burn of two cars used for testing a new type of heat shelter. The intensity of the fire line was extremely high and, notwithstanding the successful performance of these innovative protective devices, some uncovered parts of the cars, especially tires, were seriously burned.

On the second day of experiments, $\mathrm{NO}_{2}$ and $\mathrm{SO}_{2}$ concentrations were generally lower than those acquired on the previous day for both PFS and TFS. Plots burned on the first day were closer to the passive samplers than those burned on the second day (Fig. 3).

The night period (from 6 p.m. 30 May to 9 a.m. 31 May) was not used to estimate firefighter exposure. Concerning the results of passive samplers used by firefighters and research team members, hourly concentrations of $\mathrm{NO}_{2}$ and $\mathrm{SO}_{2}$ were 
Table 6. Hourly averaged concentration values for temporary-fixed samplers (TFS)

\begin{tabular}{lcccccc}
\hline TFS location & \multicolumn{3}{c}{$30 \mathrm{May} 2002$} & & $31 \mathrm{May}_{2002}$ & \\
& Exposure period & $\mathrm{NO}_{2}\left(\mu \mathrm{g} \mathrm{m}^{-3}\right)$ & $\mathrm{SO}_{2}\left(\mu \mathrm{g} \mathrm{m}^{-3}\right)$ & Exposure period & $\mathrm{NO}_{2}\left(\mu \mathrm{g} \mathrm{m}^{-3}\right)$ & $\mathrm{SO}_{2}\left(\mu \mathrm{g} \mathrm{m}^{-3}\right)$ \\
\hline TFS1 & $9: 19-14: 42$ & 61 & 29 & $8: 22-15: 48$ & 24 & 24 \\
TFS2 & $9: 14-14: 40$ & 58 & 26 & $8: 25-15: 47$ & 24 & 14 \\
TFS3 & $9: 11-14: 35$ & 64 & - & $8: 27-15: 46$ & 21 & 12 \\
TFS4 & $9: 09-12: 40$ & 85 & - & $8: 30-15: 43$ & 24 & 13 \\
TFS5 & $9: 06-12: 41$ & 92 & 33 & $8: 15-15: 45$ & 23 & 10 \\
TFS6 & $9: 03-12: 44$ & 105 & 36 & $8: 19-15: 40$ & 0 & 12 \\
TFS7 & $9: 00-12: 47$ & 79 & 60 & $8: 23-15: 37$ & 29 & 13 \\
TFS8 & $8: 56-14: 40$ & 69 & 56 & $8: 21-15: 38$ & 29 & 13 \\
TFS9 & $8: 53-14: 42$ & 181 & 35 & $8: 25-15: 30$ & 35 & \\
TFS10 & $8: 50-14: 38$ & 124 & 17 & $8: 36-15: 35$ & & \\
TFS1 & $14: 42-17: 47$ & 85 & 57 & & & \\
TFS2 & $14: 42-17: 50$ & 94 & 33 & & & \\
TFS3 & $14: 36-17: 53$ & 90 & 27 & & & \\
TFS4 & $12: 40-17: 40$ & 94 & 19 & & & \\
TFS5 & $12: 42-17: 58$ & 72 & 15 & & & \\
TFS6 & $12: 45-18: 07$ & 33 & 14 & & & \\
TFS7 & $12: 47-18: 05$ & 55 & 16 & & & \\
TFS8 & $14: 46-18: 04$ & 80 & 48 & & & \\
TFS9 & $14: 42-17: 53$ & 66 & 28 & & & \\
TFS10 & $14: 38-17: 59$ & 61 & 26 & & & \\
\hline
\end{tabular}

Table 7. Hourly averaged concentration values for mobile samplers (MS)

\begin{tabular}{lccc}
\hline MS & Exposure period & $\begin{array}{c}\mathrm{NO}_{2} \\
\left(\mu \mathrm{g} \mathrm{m}^{-3}\right)\end{array}$ & $\begin{array}{c}\mathrm{SO}_{2} \\
\left(\mu \mathrm{g} \mathrm{m}^{-3}\right)\end{array}$ \\
\hline Firefighter 1 & $9: 51(30)-17: 30(31)$ & 38 & 5 \\
Firefighter 2 & $9: 46(30)-15: 10(31)$ & 52 & 6 \\
Firefighter 3 & $9: 46(30)-15: 10(31)$ & 50 & 7 \\
Firefighter 4 & $9: 44(30)-15: 10(31)$ & 48 & 9 \\
Firefighter 5 & $9: 40(30)-17: 30(31)$ & 30 & 4 \\
Team member 1 & $10: 17-15: 10(31)$ & 67 & 12 \\
Team member 2 & $10: 17-15: 10(31)$ & 57 & 21 \\
\hline
\end{tabular}

higher in the team members' samplers (Table 7). One possible cause of this unexpected difference could be the fact that those were the team members involved in the smoke sampling with Tedlar bags (for VOC analysis) and, despite the much smaller exposure time, this procedure requires very close contact with smoke. The registered $\mathrm{NO}_{2}$ values do not seem of concern if compared with the established hourly limit value for the protection of human health by European legislation $\left(260 \mu \mathrm{g} \mathrm{m}^{-3}\right) . \mathrm{SO}_{2}$ concentrations do not seem to be a problem at all when compared with the legislation; its hourly limit value is $350 \mu \mathrm{g} \mathrm{m}^{-3}$.

VOC samples were taken just close to the burning plots and the values obtained should be considered as emissions and not air quality values. Table 8 summarises the measured values. Separate VOC samples were taken during the flaming (first sample) and the smouldering (second sample) phases. With the exception of plots 514, 515 and 518, the values acquired indicate different emissions for those two stages, with smaller VOC concentrations emitted during the flaming

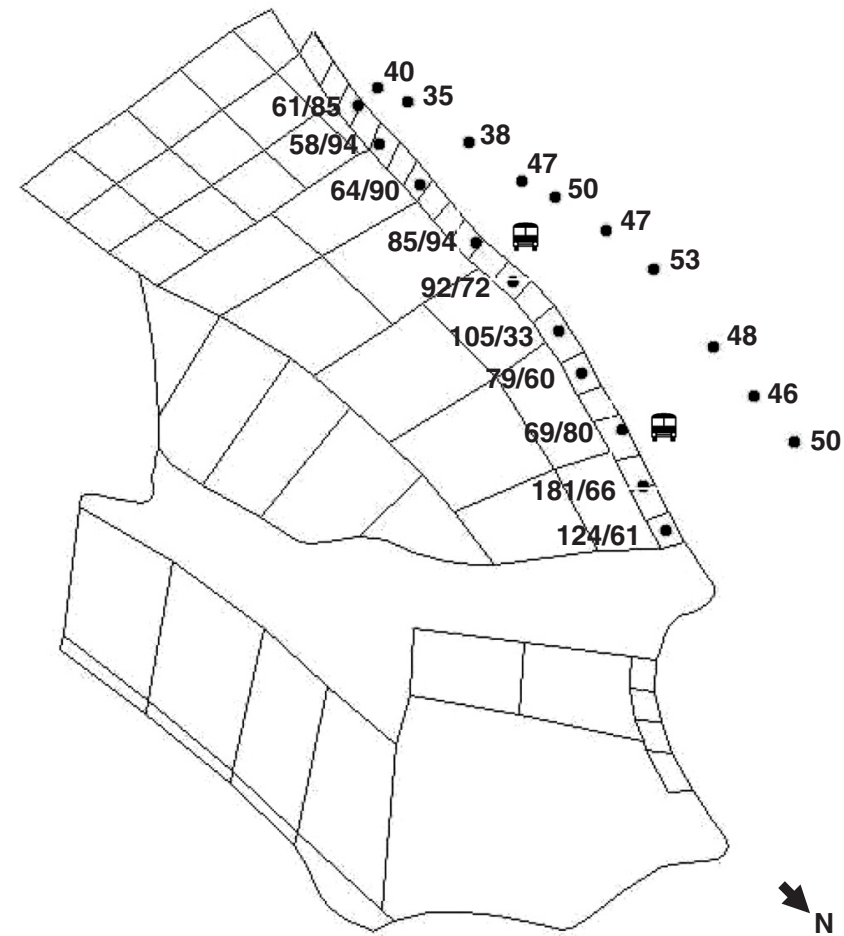

Fig. 8. Spatial distribution of hourly $\mathrm{NO}_{2}$ concentrations (morning/ afternoon values for temporary-fixed samplers and daily values for permanent-fixed samplers) for 30 May.

phase than in the smouldering stage (Table 8). Concentration values acquired for plots 514,515 and 518 are very similar for both samplings. In addition, for plots 520 and 519 only one sampling was possible. 
Table 8. Volatile organic compound (VOC) concentrations sampled

\begin{tabular}{lccc}
\hline Day & Plot burned & Local time & VOC $\left(\mathrm{mg} \mathrm{Nm}^{-3}\right)$ \\
\hline 30 May 2002 & 513 & $10: 30$ & 7.0 \\
& 513 & $10: 35$ & $17.7^{\mathrm{A}}$ \\
& 517 & $11: 35$ & 14.3 \\
& 517 & $11: 45$ & $27.3^{\mathrm{A}}$ \\
& 516 & $12: 29$ & 8.5 \\
& 516 & $12: 30$ & $19.3^{\mathrm{A}}$ \\
& 514 & $13: 28$ & 7.5 \\
& 514 & $13: 34$ & 5.4 \\
& 515 & $16: 34$ & 15.4 \\
& 515 & $16: 36$ & 13.3 \\
& 518 & $17: 13$ & 8.3 \\
& 518 & $17: 15$ & 6.5 \\
May 2002 & 522 & $11: 32$ & 17.7 \\
& 522 & $11: 40$ & $49.8^{\mathrm{A}}$ \\
& 521 & $12: 33$ & 9.5 \\
& 521 & $12: 38$ & $32.1^{\mathrm{A}}$ \\
& 520 & $14: 04$ & 22.5 \\
& 519 & - & 5.3 \\
\hline
\end{tabular}

${ }^{\text {A }}$ Smaller VOC concentrations emitted during the flaming phase than in the smouldering stage.

The Portuguese emission limit value for anthropogenic VOC is $50 \mathrm{mg} \mathrm{Nm}^{-3}$. Although the concentrations measured during the experiments did not exceed this limit, even for the smouldering emissions, they are quite significant.

\section{Conclusions}

A series of field experiments of fire spread in shrub vegetation on slopes have been performed in Portugal since 1998, in which the University of Aveiro has participated with emissions and air quality measurements. During the 2002 event, it was possible to distinguish the different contributions of flaming and smouldering stages on VOC emissions to the atmosphere. In fact, the concentrations emitted by the latter are more than two times higher, leading to the conclusion that the combustion stage has an intense effect on vegetation burning emissions. This conclusion is in agreement with the results obtained during fire experiments performed by other authors (Crutzen and Andreae 1990; Lobert and Warnatz 1993).

The maximum hourly averaged concentrations of $\mathrm{NO}_{2}$ and $\mathrm{SO}_{2}$ reached in the fixed samplers were 181 and $60 \mu \mathrm{g} \mathrm{m}^{-3}$ respectively. These values are less than those established by the European legislation (200 and $350 \mu \mathrm{g} \mathrm{m}^{-3}$ respectively). The maximum hourly concentrations found for these pollutants with the mobile samplers carried by operational people were 67 and $21 \mu \mathrm{g} \mathrm{m}^{-3}$ respectively. However, significantly higher values of $\mathrm{NO}_{2}$ ( of $\sim 265 \mu \mathrm{g} \mathrm{m}^{-3}$ ) were registered during 2003 and 2004 fire experiments in Gestosa (Miranda et al. 2004), allowing the conclusion that, depending on the specific task of each firefighter involved in ground-based operations, the exposure to high levels of pollutants can be expected. A similar conclusion was reached from the intensive measurements performed by the USDA Forest Service during wildfires and prescribed burns (Reinhardt and Ottmar 2000; Reinhardt et al. 2000).

Concerning data acquired by the automatic equipment installed inside the luggage vans, and despite the small size of the burning plots when compared to real wildfires, the measured levels of both categories of particles attained values considered hazardous to human health, $3000 \mathrm{\mu g} \mathrm{m}^{-3}$, 15 min average. Maximum $\mathrm{PM}_{2.5}$ and $\mathrm{PM}_{10}$ hourly averaged

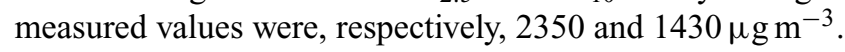
For comparison purposes, the hourly averaged values measured in operational conditions during a wildfire in Greece reached 335 and $1300 \mu \mathrm{g} \mathrm{m}^{-3}$, respectively (NTUA 2004), indicating that in particular the $\mathrm{PM}_{2.5}$ value registered in the Gestosa-2002 fire experiments was very high. These measurements reinforce the idea that firefighters are exposed to unhealthy air pollutant concentrations during their daily activity. Regarding the recorded $\mathrm{CO}$ and $\mathrm{NO}_{2}$ values it can be concluded that, in this specific situation, these pollutants did not attain disturbing concentrations. None of the pollutants surpassed the established limit values in the European legislation. In conclusion, it can be inferred that the most critical situation in terms of air quality that occurred during the experimental fires of Gestosa-2002 was posed by the emission of particulate matter.

Experimental field fires represent a valuable tool for understanding wildfires in all their aspects: how they behave, how they affect the environment or health, or how they can be extinguished efficiently. However, in relation specifically to the exposure and resulting adverse health effects of smoke on personnel involved in fire-fighting operations, more information is still needed and field experiments such as Gestosa should be encouraged.

\section{Acknowledgements}

First of all, the authors recognise the importance of D. X. Viegas' coordinating work in the acquisition of required information. Also, an acknowledgment is due to all the colleagues who participated in this work, and in particular to IDAD for its technical assistance during the field measurements. This work was developed under the framework of the project SPREAD (EVGI-2001-00027). The authors are grateful for the financial support of the Third EU Framework Program and the Portuguese 'Ministério da Ciência e do Ensino Superior', for the PhD grants of J. Ferreira (SFRH/ BD/3347/2000) and J. H. Amorim (SFRH/BD/11044/2002), and for the research grants of J. Valente and P. Santos in the scope of ERAS European Project (EVGI-2001-000919).

\section{References}

Andreae M, Merlet P (2001) Emission of trace gases and aerosols from biomass burning. Global Biogeochemical Cycles 15, 955-966. doi:10.1029/2000GB001382 
Core J (2001) Visibility. In 'Smoke management guide for prescribed and wildland fire'. (Eds CC Hardy, RD Ottmar, JL Peterson, JE Core, P Seamon) pp. 35-39. (National Wildfire Coordination Group)

Crutzen P, Andreae M (1990) Biomass burning in the tropics: impact on atmospheric chemistry and biogeochemical cycles. Science 250, 1669-1678.

Frampton MW, Morrow PE, Cox C, Gibb FR, Speers DM, Uttel MJ (1991) Effects of nitrogen dioxide exposure on pulmonary function and airway reactivity in normal humans. The American Review of Respiratory Disease 143, 522-527.

Lobert J, Warnatz J (1993) Emissions from the combustion process in the vegetation. In 'Fire in the environment. The ecological, atmospheric, and climatic importance of vegetation fires'. (Eds P Crutzen, J Goldammer) pp. 15-37. (John Wiley \& Sons: Chichester)

Martins H, Carvalho A, Miranda AI, Salmim L, Sousa M (2004) Incêndios florestais periurbanos e qualidade do ar. In 'Proceedings of the 8th conferência nacional de ambiente', Lisbon, Portugal, 27-29 October. pp. 379-381.

Miranda AI, Borrego C (2002) Air quality measurements during prescribed fires. In 'Proceedings of IV international conference on forest fire research, Luso-Coimbra, Portugal, 18-23 November 2002-Forest fire research \& wildland fire safety'. (Ed. DX Viegas) p. 205. (Millpress: Rotterdam)

Miranda AI, Valente J, Amorim JH, Santos P, Ferreira J, Borrego C (2004) Medição de poluentes atmosféricos resultantes de fogos experimentais em ensaios de campo. In 'Proceedings of the 8th conferência nacional de ambiente', Lisbon, Portugal, 27-29 October. pp. $379-381$.

NTUA (2004) Unpublished data from the EC ERAS Project (EVGI2001-000919).

Penkett SA, Law KS, Cox T, Kasibhatla P (2003) Atmospheric photooxidants. In 'Atmospheric chemistry in a changing world, an integration and synthesis of a decade of tropospheric chemistry research'. (Eds GP Brasseur, RG Prinn, AAP Pszenny) pp. 73-124. (Springer: Heidelberg)
Reinhardt TE, Ottmar RD (2000) 'Smoke exposure at western wildfires.' USDA Forest Service, Pacific Northwest Research Station Research Paper PNW-RP-525. (Portland, OR)

Reinhardt TE, Ottmar RD, Hanneman AJS (2000) 'Smoke exposure among firefighters at prescribed burns in the Pacific Northwest.' USDA Forest Service, Pacific Northwest Research Station Research Paper PNW-RP-526. (Portland, OR)

Riebau A, Fox D (2001) The new smoke management. International Journal of Wildland Fire 10, 415-427. doi:10.1071/WF01039

Utkin AB, Fernandes A, Simões F, Lavrov A, Vilar R (2003) Feasibility of forest-fire smoke detection using lidar. International Journal of Wildland Fire 12, 159-166. doi:10.1071/WF02048

Viegas DX (2002) Gestosa 2002 News No. 7. Bulletin with News and Data on the Gestosa 2002. ADAI-Coimbra, Portugal. (Ed. DX Viegas)

Viegas DX, Cruz MG, Ribeiro LM, Silva AJ, Ollero A, et al. (2002) Gestosa fire spread experiments. In 'Proceedings of IV international conference on forest fire research', Luso-Coimbra, Portugal, 18-23 November 2002-Forest fire research \& wildland fire safety. (Ed. DX Viegas) pp. 121. (Millpress: Rotterdam)

Ward D, Radke L (1993) Emissions measurements from vegetation fires: a comparative evaluation of methods and results. In 'Fire in the environment. The ecological atmospheric and climatic importance of vegetation fires'. (Eds P Crutzen, J Goldammer) pp. 53-76. (John Wiley \& Sons: Chichester)

WHO (2000) 'Air quality guidelines for Europe, 2nd edn.' WHO Regional Publications, European Series, No. 91. (World Health Organization, Regional Office for Europe: Copenhagen)

WHO/UNEP/WMO (1999) 'Health guidelines for vegetation fire events-Guideline document.' (Eds D Schwela, JG Goldammer, L Morawska, O Simpson) (United Nations Environment Program: Nairobi; World Health Organization: Geneva; World Meteorological Organization: Geneva; Institute of Environmental Epidemiology, WHO Collaborating Centre for Environmental Epidemiology, Ministry of the Environment: Singapore) 